\title{
Anterior suspended flaps: a modified approach for external dacryocystorhinostomy
}

\author{
Lelio Baldeschi, Marco Nardi, Christoph R Hintschich, Leo Koornneef
}

Neurosciences

Department of Pisa University, Section of Ophthalmology, Pisa, Italy

L Baldeschi

M Nardi

Orbital Center,

Department of

Ophthalmology,

University of

Amsterdam,

Amsterdam,

Netherlands

L Baldeschi

C R Hintschich

L Koornneef

University Eye Hospital, Ludvig

Maximilians

University of Munich, Munich, Germany

C R Hintschich

Correspondence to: Dr Lelio Baldeschi, Room A2-119, Orbital Center, Department of

Ophthalmology, Academic Medical Center, University of Amsterdam, Meibergdreef 9, 1105 AZ Amsterdam, Netherlands.

Accepted for publication 29 January 1998

\begin{abstract}
Backgroundlaims-External dacryocystorhinostomy (DCR) is a reliable but difficult surgical technique for the treatment of any obstruction of the lacrimal drainage system lying distal to the internal opening of the common canaliculus. In this prospective study, a simplified external DCR procedure and the results obtained on a series of 45 consecutive patients, in which traditional external DCR was indicated, are described.

Methods-In this modified procedure only very large and mobile anterior flaps of the lacrimal sac and nasal mucosa are created. Thanks to the large size and the great motility the two flaps can be easily sutured. Two double armed $6 / 0$ polyglycolic acid sutures are used to join the two flaps, to elevate them anteriorly in order to avoid adhesions with underlying tissues, and to approximate the deep planes of the wound. The mean operative time was measured.

Results-At the end of follow up period (mean 17 months, range 14-24 months) all patients had no sign or symptoms of tearing and normal Jones I dye test. The mean operative time was 28.6 minutes (range 23-44 minutes)

Conclusion-We believe that our modified technique can be used to simplify and speed up traditional external DCR without decreasing its well known reliability. (Br f Ophthalmol 1998;82:790-792)
\end{abstract}

Obstruction of the lacrimal drainage system occurs most often at either the junction of the sac and the nasolacrimal duct or within the bony nasolacrimal duct. Reconstruction of the lacrimal passages in such cases can be achieved by several surgical techniques, although external dacryocystorhinostomy (DCR), proposed by Ohm and by Dupuy-Dutemps and Bourguet in $1921,{ }^{12}$ is still the most successful operation. $^{3-5}$

DCR is not an easy surgical procedure, and good results are only achieved in skilled hands. In this prospective study, a simplified external DCR procedure and the results obtained on a series of 45 consecutive patients are described.

This modification of external DCR has not been previously published to the authors' knowledge.

\section{Patients and methods}

Forty five consecutive patients (mean age 62 years, range 34-79), presenting with unilateral obstruction of the lacrimal drainage system distal to the internal ostium of the common canaliculus were included in our study. All patients presented a negative Jones I dye test, 34 patients had epiphora, seven epiphora and dacryocystitis, three epiphora and mucocele, one mucocele.

Forty two patients underwent day case surgery under local anaesthesia after mild sedation, while the other three opted for general anaesthesia and required an overnight stay.

The mean operative time was measured.

\section{SURGICAL PROCEDURE}

A straight $20 \mathrm{~mm}$ skin incision placed 10-12 $\mathrm{mm}$ nasal to the medial canthus and tangential to the inferonasal rim of the orbit is made.

Next the orbicularis muscle is bluntly dissected, and the anterior limb of the medial canthal tendon and the periosteum are exposed.

The skin and the orbicularis muscle are then raised medially and laterally with four traction sutures of $4 / 0$ silk.

The periosteum is then incised about $3 \mathrm{~mm}$ anterior and parallel to the anterior lacrimal crest. The medial flap is reflected forwards for about $10 \mathrm{~mm}$ and raised from the bone with traction sutures (it might be used as a nasal mucosa-like flap in case the last one is damaged, otherwise it is resected at the end of the operation). The lateral flap is elevated with the medial canthal tendon towards the anterior lacrimal crest and the lacrimal sac is then reflected laterally from the floor of the lacrimal fossa.

After this, an osteotomy, $15 \times 15 \mathrm{~mm}$ wide, in the lateral nasal wall is created and the nasal mucosa exposed. The bony window includes the entire anterior lacrimal crest, lacrimal fossa, and superomedial wall of the nasolacrimal canal. If an anterior ethmoidal cell is entered, the bony aperture is extended in order to expose the nasal mucosa. Nasal mucosa is two to three times thicker than ethmoidal mucosa and less friable and this easy enables the surgeon to identify his or her anatomical location. ${ }^{6}$

Next, large anterior flaps of lacrimal sac and nasal mucosa are created, as big and mobile as possible. They are joined as follows: two double armed 6/0 polyglycolic acid sutures are passed through the superior and inferior angles of the flaps and closed (Fig 1), one end of each suture is then passed through the orbicularis muscle at the medial edge of the wound and the other is passed through the orbicularis muscle at the lateral edge and closed again (Fig 2). In this way three results are simultaneously achieved: (1) the two flaps are joined; (2) they are elevated 


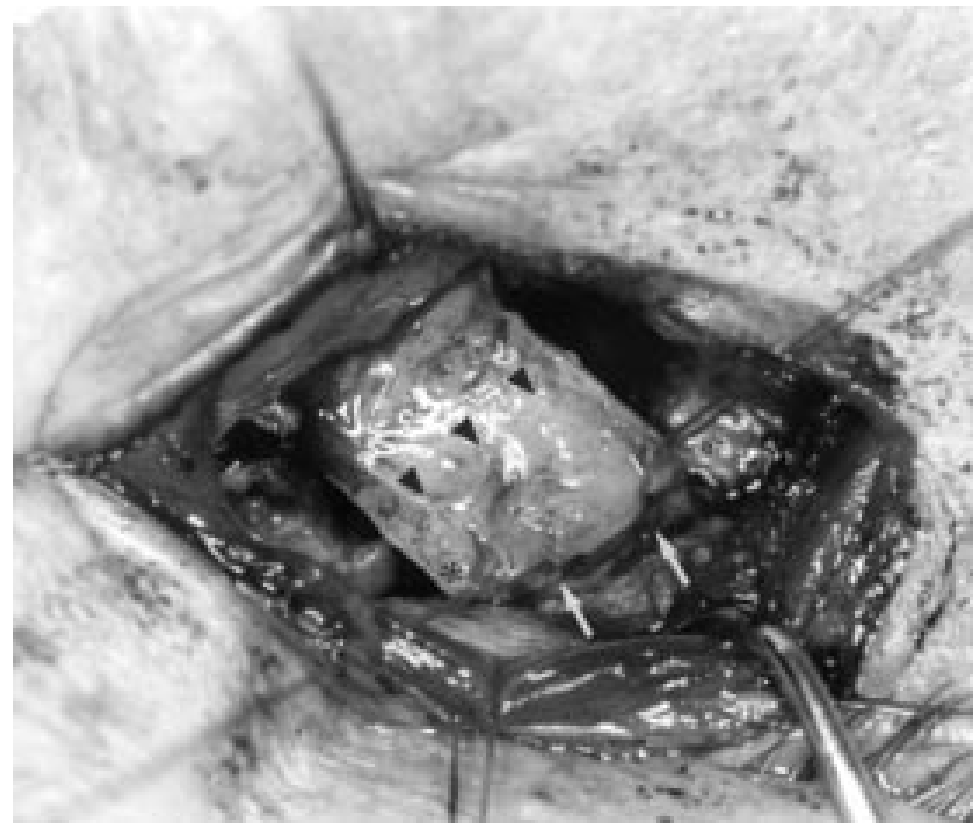

Figure 1 Large anterior flaps of lacrimal sac (arrows) and nasal mucosa (arrowheads) are joined with two double armed 6/0 polyglycolic acid sutures (asterisks) which are passed through the superior and inferior angles of the flaps.

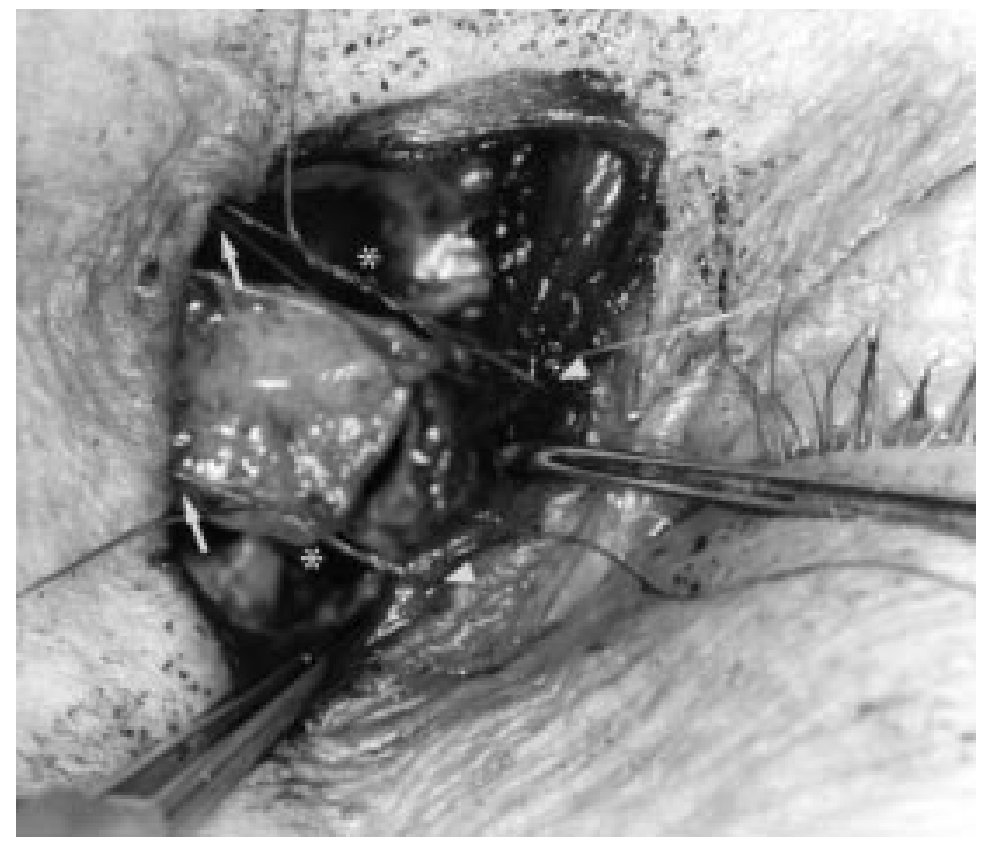

Figure 2 One end of each double armed suture, used to join the mucosal flaps, is passed through the orbicularis muscle at the medial edge of the wound (arrows), the other end through the orbicularis muscle at the lateral edge (arrowheads). Each suture is then closed again (asterisks). surgery. The use of steroid drops and systemic antibiotics is recommended for 1 week after surgery. ${ }^{7-9}$

FOLLOW UP

The patency of the dacryocystorhinostomy was examined after 7, 14, 30 days and later every 4 months for the first 2 years. During the first examinations if the dacryocystorhinostomy was found to be blocked, probing was performed, clots were removed, and the use of steroid drops and systemic antibiotics prolonged for one more week.

\section{Results}

On postoperative day 7, two cases needed probing and clot removal (one of them was a patient with severe coagulation problems due to thrombocytopenia) while five cases needed only probing. On postoperative day 14 further probing was necessary for two of them.

Mean follow up was 17 months (range 14-24 months). At the end of follow up period, all patients had no sign or symptoms of tearing and normal Jones I dye test.

The mean operative time was 28.6 minutes (range 23-44 minutes).

\section{Discussion}

Since Toti in $1904,{ }^{10} \mathrm{Ohm},{ }^{1}$ and DupuyDutemps and Bouguet ${ }^{2}$ in 1921 laid the foundation of the modern external DCR, several alternatives techniques such as nasolacrimal duct intubation, ${ }^{11}$ endoscopic and nonendoscopic endonasal DCR, ${ }^{12-16}$ and endonasal or transcanalicular laser $\mathrm{DCR}^{17-20}$ have been proposed.

Intubation of the nasolacrimal duct was first described in $1944 .{ }^{11}$ The results obtained with this technique are poor and variable ${ }^{21}{ }^{22}$; the risk of foreign body reaction induced by the tubes is great. ${ }^{23-25}$

Endonasal DCR is used infrequently even if it does not damage the lacrimal pump, does not cause cutaneous scars, and presents a success rate similar to external DCR. ${ }^{15-17}$

Use of endonasal rigid endoscopes which allow an excellent visualisation and a good surgical access to the medial lacrimal fossa have increased the popularity of this technique. ${ }^{1420}$

When compared with a more modern technique such as laser DCR, external DCR is said to result in scarring, greater tissue damage, and frequent haemorrhages. Moreover, patients seems to prefer the laser approach rather than traditional one. ${ }^{417}$ Each of these points can be countered. The cutaneous scar from external DCR rarely causes serious cosmetic problems, especially if the incision respects relaxed skin tension lines. ${ }^{26}$ Even if tissue damage due to the laser approach is minimal, in clinical practice supplementary turbinectomy or septoplasty may be necessary. ${ }^{27}$ In addition, the rhinostomy often needs to be enlarged with standard nasal instruments to facilitate silicone intubation. ${ }^{4}$ The risk of bleeding during laser DCR has not been eliminated and it is comparable with the risk during external DCR. ${ }^{5}{ }^{28}$ The preference accorded by many patients for laser DCR is drops and adrenaline $0.1 \%$ drops is insert into the nose (against its lateral wall between the middle and inferior turbinate) before 
often the result of unjustified emphasis on the absence of cutaneous scar and to poor outline of the risks and benefits of the procedure. Endonasal laser DCR, for example, presents a long term success rate of $75 \%{ }^{18}$ versus 90-100\% of external DCR. ${ }^{4}$ It is impossible after trauma or in the presence of an altered bony anatomy of the region. ${ }^{18}$ Endonasal and endocanalicular laser DCR are contraindicated if the presence of tumour or dacryolith is suspected: laser DCR, in fact, does not permit any incisional or excisional biopsy of these lesions.

External DCR, proposed more than 70 years ago, is a reliable operation. However, external DCR is not an easy surgical procedure and requires considerable operative time. Its limitations are the difficult resection and suture of the mucosal flaps, and the possible postoperative closure of the newly created lacrimal tract, either by formation of granulation tissue at the osteotomy level or by adhesion of the anterior to the posterior flaps. ${ }^{29}$

To overcome the limits of traditional external DCR, several authors have suggested modifications. ${ }^{29-35}$ In this same context we feel that the procedure described here serves as a rational extension of these attempts.

Thus, making anterior flaps only is a common variation of external DCR; in our modified technique they have been created oversized on purpose in order to facilitate their surgical manipulation. Then, they are suspended in order to avoid their possible adhesion to the deeper tissues, which is one of the rare causes of failure of external DCR. ${ }^{29} \mathrm{At}$ the same time, the sutures used to suture and suspend the mucosal flaps close the deep planes of the wound, again speeded up the procedure.

Though the suturing of the anterior and posterior mucosal flaps increases the probability of primary healing of the mucosal anastomosis and reduces the tendency to primary and secondary haemorrhages as pointed out by Jones and Welham, ${ }^{36}$ we have found it simpler in lacrimal surgery to use anterior suspended flaps only.

We believe that this simplified DCR procedure is easy and quick to perform. Thanks to its simplicity it may be suitable not only for oculoplastic surgeons but also for ophthalmologists whose main area of interest is not lacrimal surgery. The results of this study demonstrate the reliability of our modification even if a larger series of cases would be more conclusive.

$1 \mathrm{Ohm}$ J. Bericht über 70 totische operazionen. $Z$ Augenheilkd 1921;46:37-45

2 Dupuy-Dutemps L, Bourguet M. Procede plastique de dacryocystorhinostomie et ses results. Ann Ocul 1921;158: 241-61.
3 Jain SC, Srivastava SP, Saini VK. Intubation of the sac and naso lacrimal duct in chronic dacryocystitis by a specially
designed polyethylene tube. In: Yamaguchi M, ed. Recent designed polyethylene tube. In: Yamaguchi M, ed. Recent advances on the lacrimal system. Kyoto: XXIII Internation
Congress of Ophthalmology 12-13 May 1978:158-62.

4 Bartley GB. The pros and cons of laser dacryocystorhinostomy. Am f Ophthalmol 1994;117:103-6.

5 Burns JA, Cahill KV. Modified Kinosian dacryocystorhinostomy: a review of 122 cases. Ophthalmic Surg 1985;16:710-6.

6 Talks SJ, Hopkisson B. The frequency of entry into an ethmoidal sinus when performing a dacryocystorhinostomy. Eye 1996;10:742-3.

7 Patrinely JR, Gigantelli JW. Dacryocystorhinostomy. In: Linberg JV, ed. Lacrimal surgery. New York: Churchill Livingstone, 1988:151-67.

8 Walland MJ, Rose GE. Soft tissue infections after open lacrimal surgery. Ophthalmology 1994;101:608-11.

9 Walland MJ, Rose GE. Factors affecting the success rate of open lacrimal surgery. Br f Ophthalmol 1994;78:888-91.

10 Toti A. Nuovo metodo conservatore di cura radicale delle suppurazioni croniche del sacco lacrimale (dacriocistorinostomia). Clin Moderna Firenze 1904;10:385-7.

1 Summerskill WH. Dacryocystorhinostomy by intubation. Br f Ophthalmol 1952;36:240-4

12 West J. Eine neue method zur operation des tranensaches von der nase aus. Arch Laryngol Rhinol 1911;24:62-4.

13 Halle M. Zur intranasalen operation am tranensack. Arch Laryngol Rhinol 1914;28:256-66.

14 Rice DH. Endoscopic intranasal dacryocystorhinostomy results in four patients. Arch Otolaryngol Head Neck Surg 1990;116:1061.

15 Steadman GM. Transnasal dacryocystorhinostomy. Otolaryngol Clin North Am 1985;18:107-11.

16 Jokinen K, Karjä J. Endonasal dacryocystorhinostomy. Arch Otolaryngol Head Neck Surg 1974;100:41-4.

17 Massaro BM, Gonnering RS, Harris GJ. Endonasal laser dacryocystorhinostomy - a new approach to nasolacrimal duct obstruction. Arch Ophthalmol 1990;108:1172-6.

18 Gonnering RS, Lyon DB, Fisher JC. Endoscopic laser assisted lacrimal surgery. Am f Ophthalmol 1991;111:1527.

19 Piaton JM, Limon S, Ounnas N, et al. Endodacryocystorhinostomie transcanaliculaire au laser neodimium:YAG. $\mathcal{F} \mathrm{Fr}$ Ophtalmol 1994;17:555-67.

20 Rice DH. Endoscopic intranasal dacryocystorhinostomy: a cadaver study. Am $\mathcal{F}$ Rhinol 1988;2:128.

21 Dejean C. Les causes d'insucces dans l'intubation lacrymale. Arch Ophthalmol 1955;15:474-8.

22 Vicencio AB. Use of nylon thread and polyethylene tubing in naso-lacrimal duct stenosis. Arch Ophthalmol 1956;55: 267-8.

23 Singh DS, Garg RS. Polyethylene intubation of the naso lacrimal duct in chronic dacryocystitis. Br F Ophthalmol 1972; 56:914-18.

24 Von Below H, Rose GE. Adult nasolacrimal duct bypass tubes: where do they go? Br f Ophthalmol 1993;77:449-50.

25 Rizzo S, Baldeschi L, Frezzotti P, et al. A case of a late complication after naso lacrimal duct intubation. Eye 1995;9: $801-2$

26 Harris GJ, Sacol PJ, Beatty RL. Relaxed skin tension line incision for dacryocystorhinostomy. Am $\mathcal{F}$ Ophthalmol 1989;108:742-3.

27 Wesley RE, Bond JB. Intranasal procedures for successful lacrimal surgery. Ophthalmic Plast Reconstr Surg 1986;2: 153-7.

28 Sweet RM, Hofmann RF. Surgical consideration for dacryocystorhinostomy with special emphasis on hemostatic techniques. Ophthalmic Surg 1983;14:317-21.

29 Picò G. A modified technique of external dacryocystorhinostomy. Am f Ophthalmol 1971:72:679-90.

30 Basterra J. Dacriocistorinostomia. Arch Oftal Hisp-Am 1926;26:385-9.

31 Kalef R. Eine vereinfachte modification der dacryocystorhinostomia externa. Z Augenheilkd 1937;91:140-57.

32 Kraupa E. Die totale extirpation des tränensackes von außen mit wiederherstellung des normalen abflusses in fälaußen mit wiederherstellung des normalen abflusse

33 Rubbrect R. La dacryo-rhinostomie. Arch Ophtal 1921;6: 165-9.

34 Fazakas A. Neue modification der dacryocystorhinostomia. Klin Monatsbl Augenheilkd 1924;73:426-30.

35 Iliff CE. A simplified dacryocystorhinostomy. Tr Am Acad Ophthal 1954;58:590-2.

36 Jones BR. Principles of lacrimal surgery. Trans Opthalmol Soc UK 1773;93:611-8.

37 Welham RAN, Wulc AE. Management of unsuccessful lacrimal surgery. Br f Ophthalmol 1987;71:152-7. 